\title{
HEAVY METAL PENETRATION INTO THE HUMAN RESPIRATORY TRACT IN VILNIUS
}

\author{
D. Valiulis, J. Šakalys, and K. Plauškaitė \\ Institute of Physics, Savanoriu 231, LT-02300 Vilnius, Lithuania \\ E-mail: sakalys@ar.fi.lt
}

Received 28 August 2008; revised 19 November 2008; accepted 4 December 2008

\begin{abstract}
The peculiarities of the aerosol particle deposition in the human respiratory tract depending on the particle size and the breathing rate have been analysed. The highest deposition efficiency (0.85) was determined for the largest particles $(10-20 \mu \mathrm{m})$ and the lowest efficiency $(0.28)$ for the finer particles $(0.3 \mu \mathrm{m})$. The heavy metal amount penetrating into the human respiratory tract at a different breathing rate in Vilnius has been evaluated. It has been determined that the deposition efficiency of heavy metals in the human respiratory tract changes insignificantly with the increase in the breathing rate, and when the breathing rate increases threefold (from 10 to $30 \mathrm{~L} \mathrm{~min}^{-1}$ ) the efficiency decreases only by about $10 \%$. On the average, about $60 \%$ of heavy metals in the inhaled air penetrate into the respiratory tract. The comparison of $\mathrm{Pb}, \mathrm{V}$, and $\mathrm{Zn}$ concentrations in Vilnius city with those at the Preila background station has shown that they differ up to two times. It means that the contribution to the pollution with these metals in Vilnius city is insubstantial, and there is no considerable threat to human health.
\end{abstract}

Keywords: heavy metals, concentration, air, aerosol particles, human respiratory tract, efficiency

PACS: 92.60.Mt, 92.20.Bk, 87.19.xg

\section{Introduction}

Due to intensive anthropogenic human activity and heavy traffic in cities the air pollution with aerosol particles has increased worldwide. These particles comprise toxic materials of different origin, allergens and heavy metals, therefore airborne fine aerosol particles are harmful to human health. After penetration into a human organism during breathing they can cause the human respiratory illnesses and other disfunctions. These particles are most dangerous to people suffering from various respiratory tract diseases (e.g., asthma). Aerosol particles due to their toxicity are dangerous both to people living near the pollution sources and those who live farther because the finest particles are transported with air masses over long distances [13]. Therefore, the pollution emitted by anthropogenic sources becomes the problem not only of a separate town but also of a country, and thereby it is a global problem.

For the evaluation of the harmful impact of aerosol particles on human health, first of all their constituent damaging materials and the size of aerosol particles in which they accumulate should be investigated, as well as pollution sources of these materials, their migra- tion regularities, and their penetration into human lungs should be determined.

Depending on the lifestyle an adult inhales 15000 litres of air per day. The particle deposition on the surface of the human respiratory tract occurs due to the processes of the Brown diffusion, inert deposition, and sedimentation. The number of aerosol particles deposited in the human airway zones is called "regional deposition", while the number of particles deposited in the human airways is called "total deposition".

The human respiratory system can be divided into three zones [4]: (i) the upper respiratory zone (nose, mouth, pharynx, larynx, and the upper part of trachea) where inert deposition most frequently takes place; (ii) the tracheobronchial zone (tracheobronchial airways) where most of the particles deposit due to inert deposition and sedimentation processes. When the particle diameter is greater than $8.0 \mu \mathrm{m}$, the deposited amounts in the bronchial zone are smaller because particles are effectively retained in the upper respiratory zone; (iii) the alveolar zone where particles deposit due to sedimentation processes and the Brown diffusion. Lungs are a dichotomic bronchial system (consisting of two parts) with respiratory tract furcations [5].

The deposition of particles is determined by their 


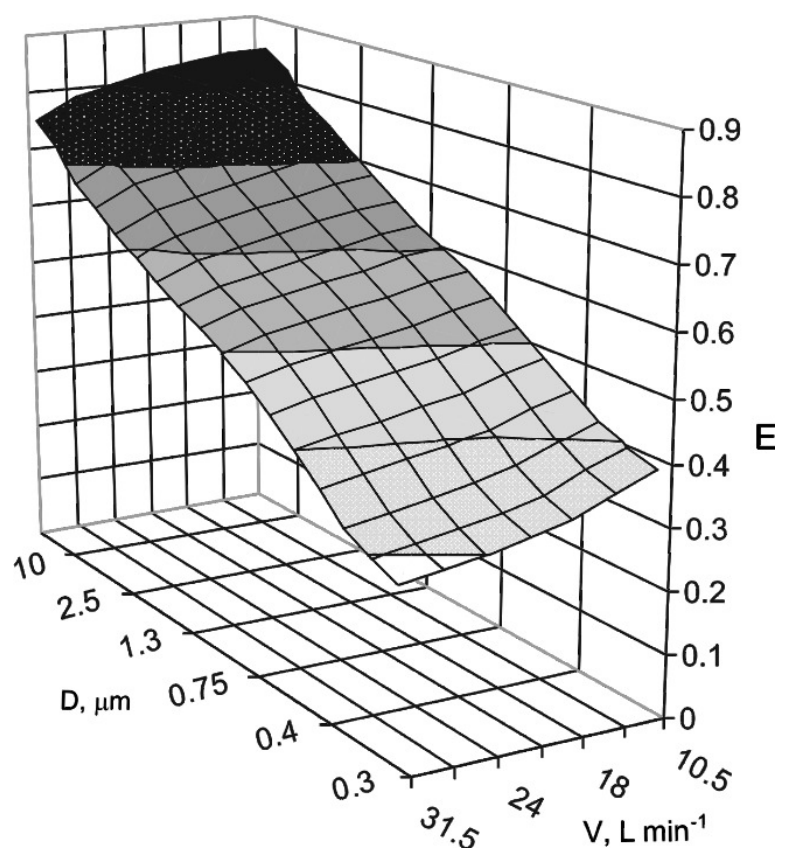

Fig. 1. Dependence of aerosol particle deposition efficiency $E$ in human lungs on the particle diameter $D$ and the breathing rate $V$.

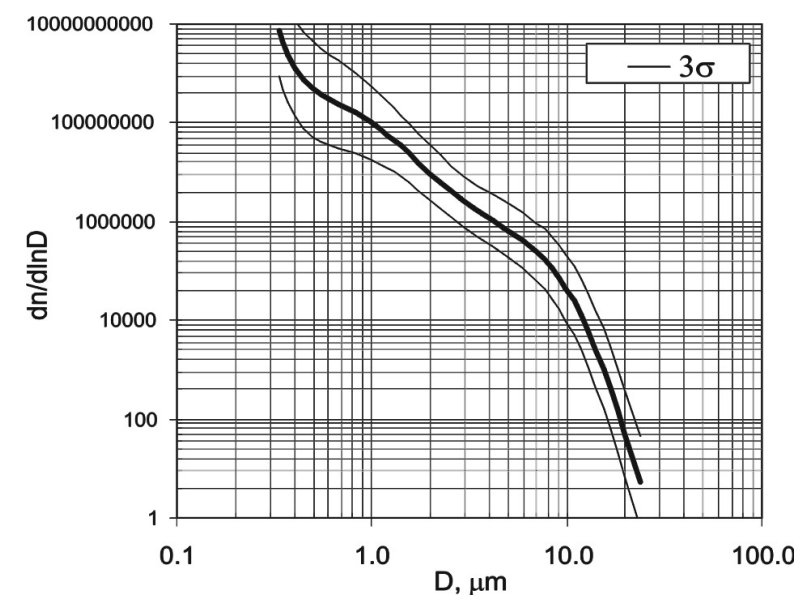

Fig. 2. Aerosol particle size spectrum in Vilnius city.

physical and chemical properties (diameter, form, and density) and breathing parameters such as the volumetric flow rate and frequency, as well as volume of inhaled and exhaled air [4]. When the particle diameter is greater than $5 \mu \mathrm{m}$, deposition in alveoli increases with the flow rate because inert deposition dominates. Particles with the diameter greater than $7 \mu \mathrm{m}$ do not penetrate into the alveolar zone, while particles with the aerodynamic diameter from $0.03 \mu \mathrm{m}$ to $2 \mu \mathrm{m}$ deposit only in the alveolar zone. Therefore, the total particle deposition in this size range is determined only by the alveolar deposition due to the Brown diffusion $[6,7]$. The total aerosol particle deposition during breathing through the nose is by $10 \%$ larger than breathing through the mouth because the nose is a very effective filter of large particles allowing penetration of half the particles of $3 \mu \mathrm{m}$ diameter and fully retaining particles with the diameter larger than $8 \mu \mathrm{m}$. When particles are of a submicron diameter, the total deposition both during breathing through the mouth and through the nose is the same [4].

More attention is paid to the investigations of the total deposition than that in separate parts of lungs because such investigations are simpler. All measurements are carried out during stationary breathing at the normal functional residual volume of the human lungs. The particle deposition in the human respiratory tract depends on the aerosol particle diameter: larger particles $(>1.0 \mu \mathrm{m})$ deposit due to inert deposition and sedimentation processes, while finer particles $(<0.1 \mu \mathrm{m})$ deposit due to the Brown diffusion. The particles of the intermediate diameter (from 0.1 to $1.0 \mu \mathrm{m}$ ) deposit due to all above mentioned processes $[4,8,9]$. In this zone the particle deposition efficiency is the lowest. The particle deposition efficiency also depends on the breathing rate - at a higher breathing rate the deposition efficiency of larger particles $(>3 \mu \mathrm{m})$ increases and that of smaller particles $(<3 \mu \mathrm{m})$ decreases [4].

The aim of this work was to evaluate the dependence of the aerosol particle deposition in the human respiratory tract on their sizes and breathing peculiarities as well as to evaluate the amount of heavy metals penetrating with aerosol particles into the human airways of Vilnius city citizens.

\section{Methods}

\subsection{Sampling}

Samples of aerosol particles for heavy metal analysis were collected at the Vilnius TV tower from 28 October to 20 December 1999. The sampling site representing Vilnius city was chosen in our previous investigations [10]. Daytime samples were collected between 8:00 a.m. and 9:00 p.m. and night-time samples between 10:00 p.m. and 7:00 a.m. One hour after the sampling period was set for the sample change. Aerosols were separated into fine $(<2.5 \mu \mathrm{m})$ and coarse $(>2.5 \mu \mathrm{m})$ fractions using a virtual impactor [11]. Samples were collected at a flow rate of $1 \mathrm{~m}^{3} / \mathrm{h}$ on Whatman 40 filters. Aerosol particle samples were also collected at the pollution research station in the old town of Vilnius on 28 April - 17 May 2001. Sampling was performed in the daytime at 9:00-21:00. Four holders of Whatman 40 filters were prepared for each day - three 
holders with a PM1 nozzle (impaction of particles with $D>1 \mu \mathrm{m}$ ), a PM2.5 nozzle (impaction of particles with $D>2.5 \mu \mathrm{m}$ ), and a PM10 nozzle (impaction of particles with $D>10 \mu \mathrm{m}$ ), while one holder was without a nozzle. Holders and filters were changed periodically every 15 minutes. Thus, 4 samples of aerosol particles were obtained every day.

\subsection{Analysis}

After collection of aerosol particles on Whatman 40 filters, they were extracted in $0.2 \mathrm{M} \mathrm{HNO}_{3}$ using a high power $(680 \mathrm{~W})$ ultrasonic bath for 1 hour. The preparation procedure, i.e. the acid concentration, time of the extraction, sonication power, and the overall recovery of the method, is described in detail in [12]. For all the investigated metals, the total recovery was above $90 \%$ (the highest recovery of $97 \%$ was obtained for lead). This method enabled a rapid analysis of samples, which was an essential part of the experiment, and minimized contamination (each individual sample was handled and prepared for analysis in one single vessel). Concentrations of trace metals were determined using an atomic absorption spectrophotometer PERKIN-ELMER Zee$\mathrm{man} / 3030$.

The size spectrum of aerosol particles was measured with the aerosol particle spectrometer LAS-15M developed at the Institute of Physics [21].

\section{Results}

At the beginning the dependence of the aerosol particle deposition efficiency in lungs on the breathing rate was investigated. In most of the works $[8,13,14]$ the aerosol particle deposition in the human respiratory tract is considered without investigation of the particle hygroscopic growth, which is important in comparing size spectra of inhaled and exhaled particles. The hygroscopic growth of pharmaceutical aerosol particles injected by the inhalator into the environment of different humidity has been discussed in [15]. It should be noted that pharmaceutical aerosol particles have nothing to do with urban aerosol particles. Urban aerosol particles consist of various components [16], most of which are porous and of irregular form [17], some particles are hydrophobic, others are hydrophilic, especially in the coastal zone. Aerosol particles of $\mathrm{SO}_{4}, \mathrm{NO}_{3}$, $\mathrm{NH}_{4}, \mathrm{Ca}, \mathrm{K}, \mathrm{Cl}, \mathrm{Mg}$, and $\mathrm{Na}$ make up from 20 to $40 \%$, while organic, elemental carbon, and crustal material make up the remaining part $[18,19]$. The material balance in aerosol particles in Vilnius was not done, but the
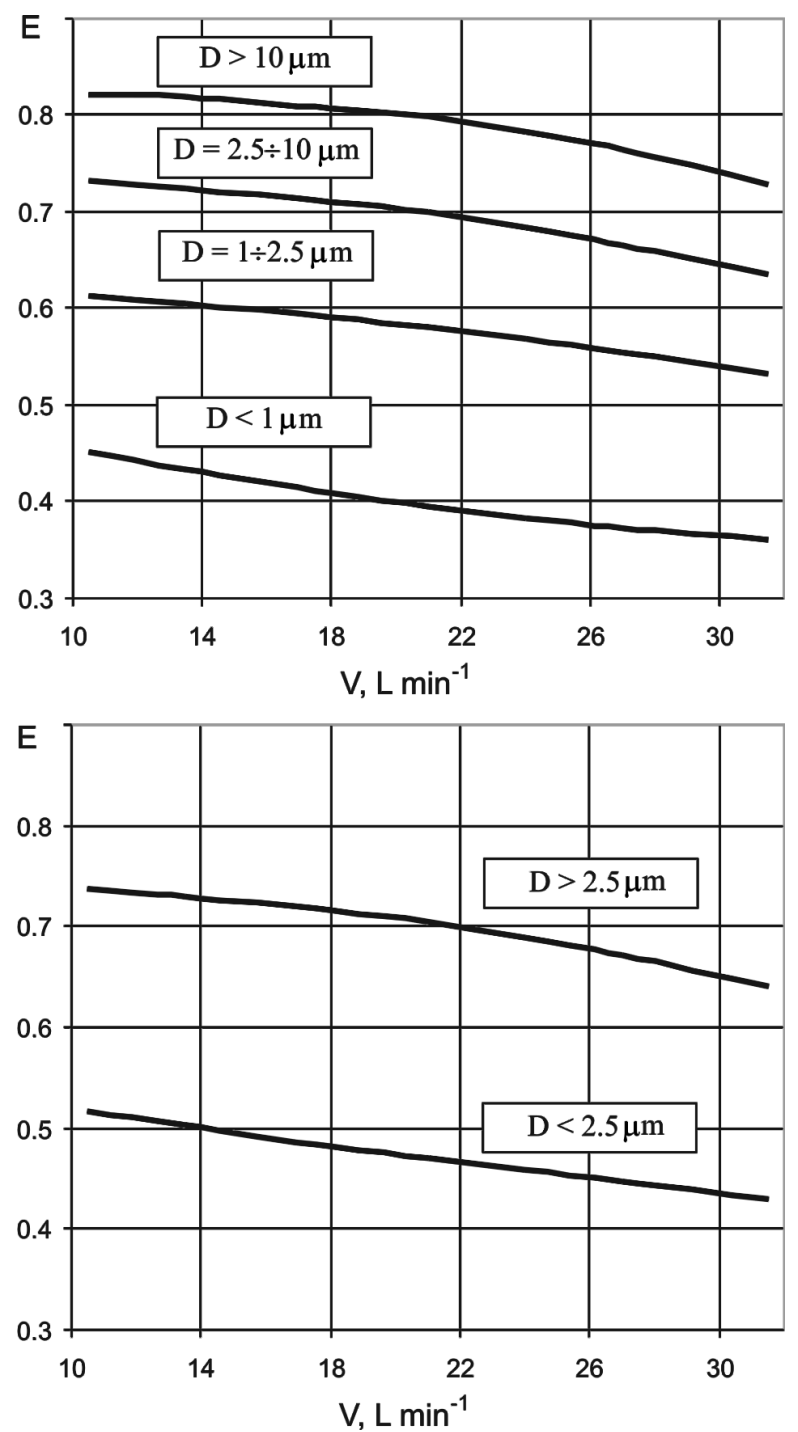

Fig. 3. Dependence of the aerosol particle deposition efficiency in lungs on the breathing rate and the particle size interval.

aerosol particle density was evaluated to be lower than that of water [20]. This shows that particles are porous, which is characteristic of hydrophobic particles, thus it was assumed that the particle growth effects are within the limits of the experimental error.

Six people aged from 20 to 60 years were selected for the experiment. The investigations were carried out by inhaling the air through the nose and exhaling through the mouth at seven different rates. The breathing rates in the range from $10 \mathrm{~L} \mathrm{~min}^{-1}$ to $32 \mathrm{~L} \mathrm{~min}^{-1}$ were chosen because the breathing rate at rest is about $10.8 \mathrm{~L} \mathrm{~min}^{-1}$, during the normal work about $20 \mathrm{~L} \mathrm{~min}^{-1}$, and during the hard work it is about $37.5 \mathrm{~L} \mathrm{~min}^{-1}$, while the average diurnal rate is about $15 \pm 3 \mathrm{~L} \mathrm{~min}^{-1}[18,19]$.

Ten measurements of the aerosol particle size spectrum at a different breathing rate were carried out: the 
Table 1. Average concentration of heavy metals $(\bar{C})$ in Vilnius city air on 28 October - 20 December 1999 ( $\sigma$ is the standard deviation, the total number of samples is 44$)$.

\begin{tabular}{cccccc}
\hline \multirow{2}{*}{ Element } & \multicolumn{3}{c}{ Concentration } & & $\bar{C} \pm \sigma), \mathrm{ng} \mathrm{m}^{-3}$ \\
\cline { 2 - 3 } \cline { 5 - 6 } & \multicolumn{2}{c}{$D<2.5 \mu \mathrm{m}$} & & \multicolumn{2}{c}{$D>2.5 \mu \mathrm{m}$} \\
\cline { 2 - 3 } \cline { 5 - 6 } & Day & Night & & Day & Night \\
\hline $\mathrm{Zn}$ & $33.0 \pm 32.8$ & $25.2 \pm 18.7$ & & $10.9 \pm 9.6$ & $20.7 \pm 69.1$ \\
$\mathrm{~Pb}$ & $13.2 \pm 16.6$ & $10.4 \pm 11.2$ & & $3.99 \pm 2.62$ & $3.78 \pm 3.29$ \\
$\mathrm{~V}$ & $2.60 \pm 1.84$ & $3.08 \pm 2.91$ & & $0.95 \pm 1.88$ & $1.28 \pm 2.25$ \\
$\mathrm{Sb}$ & $2.28 \pm 2.60$ & $1.67 \pm 1.46$ & & $1.88 \pm 3.49$ & $1.30 \pm 1.69$ \\
$\mathrm{Ba}$ & $2.49 \pm 0.78$ & $2.60 \pm 1.70$ & & $2.92 \pm 2.40$ & $2.95 \pm 2.23$ \\
\hline
\end{tabular}

Table 2. Average heavy metal concentration $(\bar{C})$ in Vilnius city air on 27 April - 17 May 2001 ( $\sigma$ is the standard deviation, the total number of samples is 21 ).

\begin{tabular}{ccccc}
\hline & \multicolumn{4}{c}{ Concentration $(\bar{C} \pm \sigma), \mathrm{ng} \mathrm{m}^{-3}$} \\
\cline { 2 - 5 } Element & $D<1 \mu \mathrm{m}$ & $1 \mu \mathrm{m}<D<2.5 \mu \mathrm{m}$ & $2.5 \mu \mathrm{m}<D<10 \mu \mathrm{m}$ & $D>10 \mu \mathrm{m}$ \\
\hline $\mathrm{Zn}$ & $11.5 \pm 1.75$ & $5.56 \pm 2.14$ & $3.06 \pm 1.42$ & $10.2 \pm 3.0$ \\
$\mathrm{~Pb}$ & $4.78 \pm 0.98$ & $0.44 \pm 0.18$ & $1.84 \pm 0.70$ & $6.98 \pm 3.54$ \\
$\mathrm{~V}$ & $0.628 \pm 0.108$ & $0.373 \pm 0.328$ & $0.300 \pm 0.074$ & $0.456 \pm 0.34$ \\
$\mathrm{Sr}$ & $0.09 \pm 0.029$ & $0.102 \pm 0.031$ & $0.029 \pm 0.014$ & $0.214 \pm 0.026$ \\
$\mathrm{Fe}$ & $7.4 \pm 2.0$ & $20.0 \pm 3.5$ & $14.5 \pm 3.3$ & $23.4 \pm 4.6$ \\
\hline
\end{tabular}

Table 3. Heavy metal amounts (minimal, median, average, and maximal) penetrating into the human respiratory tract per hour $\left(\mathrm{ng} \mathrm{h}^{-1}\right)$ in Vilnius city on 27 April - 17 May 2001 (spring period) at different breathing rates.

\begin{tabular}{cccccc}
\hline \multirow{2}{*}{ Element } & & \multicolumn{4}{c}{ Breathing rate, $\mathrm{L} \mathrm{min}^{-1}$} \\
\cline { 3 - 6 } & Value & 10 & 15 & 20 & 32 \\
\hline \multirow{2}{*}{$\mathrm{Zn}$} & min & 6.27 & 9.16 & 11.8 & 17.1 \\
& median & 11.1 & 16.2 & 21.0 & 30.3 \\
& average & 11.6 & 16.9 & 21.8 & 31.5 \\
& max & 25.3 & 36.9 & 47.7 & 68.9 \\
\hline \multirow{3}{*}{$\mathrm{Pb}$} & min & 3.20 & 4.71 & 6.10 & 8.80 \\
& median & 5.30 & 7.79 & 10.1 & 14.6 \\
& average & 5.71 & 8.39 & 10.9 & 15.7 \\
& max & 12.3 & 18.0 & 23.3 & 33.7 \\
\hline \multirow{3}{*}{$\mathrm{V}$} & min & 0.338 & 0.494 & 0.638 & 0.921 \\
& median & 0.589 & 0.860 & 1.11 & 1.60 \\
& average & 0.665 & 0.971 & 1.25 & 1.81 \\
& max & 1.76 & 2.57 & 3.32 & 4.80 \\
\hline \multirow{3}{*}{$\mathrm{Fe}$} & min & 16.5 & 24.3 & 31.6 & 45.6 \\
& median & 26.7 & 39.4 & 51.2 & 74.0 \\
& average & 27.3 & 40.2 & 52.3 & 75.6 \\
& max & 43.7 & 64.4 & 83.7 & 121 \\
\hline \multirow{3}{*}{$\mathrm{Sb}$} & min & 0.093 & 0.137 & 0.178 & 0.258 \\
& median & 0.175 & 0.258 & 0.334 & 0.484 \\
& average & 0.180 & 0.266 & 0.345 & 0.499 \\
& max & 0.400 & 0.590 & 0.766 & 1.11 \\
\hline
\end{tabular}

spectrum of airborne particles was measured for one minute and the spectrum of aerosol particles in the exhaled air was measured for the second minute. The measurement results were approximated by the leastsquares method by the second order surface (Fig. 1). The standard deviation $\sigma$ of the efficiency $E$ is 0.0267 .

For the evaluation of aerosol particle amounts penetrating into the human respiratory tract, the aerosol particle size spectrum during sampling periods should be known. During heavy metal sampling over different periods, from 28 October to 20 December in 1999 and from 27 April to 17 May in 2001, the aerosol particle size spectrum was registered. The investigation data are presented in Fig. 2. The measurement results were approximated by the least-squares method by the sixth order polynomial.

The limits of $3 \sigma$ in Fig. 2 are shown by arrows, where $\sigma$ is the standard deviation. The mass of the particle is proportional to the particle volume, therefore the deposition efficiency of aerosol particles from $D_{1}$ to $D_{2}$ in lungs is calculated taking into account the particle volume and the aerosol particle number concentration:

$$
E_{D_{1} D_{2}}=\frac{\int_{D_{1}}^{D_{2}} E(D) n(D) D^{3} \mathrm{~d} D}{\int_{D_{1}}^{D_{2}} n(D) D^{3} \mathrm{~d} D},
$$

where $E(D)$ is the deposition efficiency of $D$ diameter aerosol particles in lungs and $n(D)$ is the function of the aerosol particle concentration dependence on their diameter. 
Table 4. Heavy metal amounts (minimal, median, average, and maximal) penetrating into the human respiratory tract per hour $\left(\mathrm{ng} \mathrm{h}^{-1}\right)$ in Vilnius city on 28 October - 20 December 1999 (autumn-winter period) at different breathing rates.

\begin{tabular}{|c|c|c|c|c|c|c|c|c|c|}
\hline \multirow{3}{*}{ Element } & \multirow{3}{*}{ Value } & \multicolumn{8}{|c|}{ Breathing rate, $\mathrm{L} \mathrm{min}^{-1}$} \\
\hline & & \multicolumn{4}{|c|}{ Day } & \multicolumn{4}{|c|}{ Night } \\
\hline & & 10 & 15 & 20 & 32 & 10 & 15 & 20 & 32 \\
\hline \multirow{4}{*}{$\mathrm{Zn}$} & $\min$ & 3.49 & 5.05 & 6.49 & 9.36 & 1.91 & 2.78 & 3.59 & 5.17 \\
\hline & median & 11.1 & 16.1 & 20.7 & 29.8 & 9.19 & 13.4 & 17.3 & 24.9 \\
\hline & average & 15.1 & 21.9 & 28.1 & 40.5 & 17.0 & 24.8 & 32.0 & 46.1 \\
\hline & $\max$ & 64.7 & 93.7 & 120 & 174 & 183 & 267 & 344 & 496 \\
\hline \multirow{4}{*}{$\mathrm{Pb}$} & $\min$ & 1.16 & 1.67 & 2.15 & 3.10 & 0.348 & 0.504 & 0.648 & 0.934 \\
\hline & median & 4.06 & 5.87 & 7.54 & 10.9 & 3.43 & 4.98 & 6.39 & 9.22 \\
\hline & average & 5.88 & 8.52 & 10.9 & 15.8 & 4.90 & 7.11 & 9.13 & 13.2 \\
\hline & $\max$ & 37.4 & 54.2 & 69.5 & 100 & 27.2 & 39.5 & 50.7 & 73.1 \\
\hline \multirow{4}{*}{ V } & $\min$ & 0.291 & 0.422 & 0.542 & 0.782 & 0.075 & 0.109 & 0.140 & 0.203 \\
\hline & median & 0.918 & 1.33 & 1.71 & 2.47 & 1.07 & 1.55 & 2.00 & 2.88 \\
\hline & average & 1.23 & 1.78 & 2.29 & 3.30 & 1.52 & 2.21 & 2.84 & 4.09 \\
\hline & $\max$ & 4.53 & 6.56 & 8.43 & 12.2 & 10.2 & 14.8 & 19.1 & 27.5 \\
\hline \multirow{4}{*}{$\mathrm{Ba}$} & $\min$ & 0.747 & 1.09 & 1.41 & 2.03 & 0.442 & 0.645 & 0.833 & 1.20 \\
\hline & median & 1.78 & 2.60 & 3.36 & 4.84 & 1.79 & 2.61 & 3.37 & 4.85 \\
\hline & average & 2.07 & 3.02 & 3.90 & 5.62 & 2.12 & 3.09 & 3.99 & 5.75 \\
\hline & $\max$ & 6.48 & 9.47 & 12.2 & 17.6 & 4.95 & 7.24 & 9.34 & 13.5 \\
\hline \multirow{4}{*}{$\mathrm{Sb}$} & $\min$ & 0.070 & 0.102 & 0.131 & 0.189 & 0.058 & 0.085 & 0.110 & 0.158 \\
\hline & median & 0.819 & 1.19 & 1.54 & 2.22 & 0.617 & 0.899 & 1.16 & 1.67 \\
\hline & average & 1.54 & 2.25 & 2.90 & 4.18 & 1.09 & 1.59 & 2.05 & 2.96 \\
\hline & $\max$ & 10.6 & 15.5 & 19.9 & 28.7 & 3.36 & 9.27 & 12.0 & 17.2 \\
\hline
\end{tabular}

Referring to the dependence of the deposition efficiency of particles in lungs on their diameter and the breathing rate, and the aerosol particle concentration dependence on their diameter, and further applying Eq. (1), the deposition efficiency of aerosol particles depending on the particle size interval and the breathing rate was evaluated. Data of analysis are presented in Fig. 3.

Heavy metal concentrations of different size aerosol particles in Vilnius city are shown in Tables 1 and 2.

For comparison the data of measurements carried out at the Preila background station over the same period are presented. The average $\mathrm{Pb}$ concentration in the air was determined to be $9.06 \mathrm{ng} \mathrm{m}^{-3}, \mathrm{~V} 2.94 \mathrm{ng} \mathrm{m}^{-3}$, and $\mathrm{Zn} 19.9 \mathrm{ng} \mathrm{m}^{-3}$. By adding up concentrations of aerosol particles of $D<2.5 \mu \mathrm{m}$ and $D>2.5 \mu \mathrm{m}$ fractions in Vilnius, we obtained that concentrations of $\mathrm{Pb}$, $\mathrm{V}$, and $\mathrm{Zn}$ were $15.2,3.94$, and $44.9 \mathrm{ng} \mathrm{m}^{-3}$, respectively. We can see that the metal concentrations at the Preila background station over that period was one and a half or two times lower than those in Vilnius city. It shows that the contribution to the background level pollution with these metals in Vilnius was insubstantial, and there was no considerable threat to human health.

The determined average $\mathrm{Pb}$ concentration in the air at the Preila background station on 27 April - 17 May 2001 was $9.33 \mathrm{ng} \mathrm{m}^{-3}$, that of $\mathrm{V} 3.33 \mathrm{ng} \mathrm{m}^{-3}$, and $\mathrm{Zn} 33.3 \mathrm{ng} \mathrm{m}^{-3}$. By adding up values of $D<1 \mu \mathrm{m}$, $1 \mu \mathrm{m}<D<2.5 \mu \mathrm{m}, 2.5 \mu \mathrm{m}<D<10 \mu \mathrm{m}$, and $D>$ $10 \mu \mathrm{m}$ fractions in Vilnius city we obtained the following concentrations: $\mathrm{Pb} 14.0 \mathrm{ng} \mathrm{m}^{-3}, \mathrm{~V} 1.76 \mathrm{ng} \mathrm{m}^{-3}$, and $\mathrm{Zn} 30.4 \mathrm{ng} \mathrm{m}^{-3}$. The data of this period also show that in Vilnius city the contribution to the background level pollution with these metals was insignificant, and there was no significant danger to human health.

From the known airborne heavy metal concentration values and the dependence of the aerosol particle deposition efficiency in lungs on the breathing rate and the particle size, the amounts of metals penetrating into the human respiratory tract per hour were calculated. These data are presented in Tables 3 and 4 . As the log-normal distribution is characteristic of heavy metals in the atmosphere, the minimal, average, maximal, and median values are presented in tables. The data in Tables 3 and 4 show that the short-term heavy metal concentration can vary in a wide range by over two orders of magnitude, but the average concentration of $\mathrm{Pb}, \mathrm{V}$, and Zn during both periods, spring and autumn-winter, differed slightly. The largest difference, up to two times, was observed for vanadium. 
Table 5. Dependence of the percentage efficiency of heavy metal deposition in the respiratory tract on the breathing rate. The relative standard deviation does not exceed $3.5 \%$.

\begin{tabular}{ccccc}
\hline & \multicolumn{4}{c}{ Breathing rate, $\mathrm{L} \mathrm{min}^{-1}$} \\
Element & 10 & 15 & 20 & 32 \\
\hline $\mathrm{Zn}$ & 60.3 & 58.5 & 56.5 & 50.9 \\
$\mathrm{~Pb}$ & 59.3 & 57.5 & 55.5 & 50.1 \\
$\mathrm{~V}$ & 58.9 & 57.0 & 55.1 & 49.6 \\
$\mathrm{Sb}$ & 63.8 & 62.0 & 60.0 & 54.1 \\
$\mathrm{Ba}$ & 61.5 & 59.8 & 57.8 & 52.1 \\
$\mathrm{Sr}$ & 69.0 & 67.9 & 66.1 & 59.7 \\
$\mathrm{Fe}$ & 69.7 & 68.4 & 66.7 & 60.3 \\
\hline
\end{tabular}

The obtained data show average values of heavy metal concentrations in Vilnius city, but there are places where dustiness is significantly larger. Our measurements can be regarded as episodic because they lasted only 74 days. The percentage efficiency of heavy metal deposition in the respiratory tract could serve as a universal indicator because from the known heavy metal concentrations it would be possible to estimate their possible deposition in human airways. The dependence of the percentage efficiency of heavy metal deposition in the respiratory tract on the breathing rate is presented in Table 5. Data show that the deposition of heavy metals decreases slightly with the increase in the breathing rate, but with the threefold increase in the breathing rate the efficiency decreases only by about $10 \%$. It can be stated that on the average about $60 \%(\sigma=6 \%)$ of heavy metals present in the inhaled air penetrate into the human respiratory tract.

\section{Conclusions}

The concentration of heavy metals in different size aerosol particles in Vilnius city air has been measured. The size spectrum of aerosol particles has been determined. The efficiency of the aerosol particle deposition in the human respiratory tract depending on the particle size and the breathing rate has been analysed. The largest aerosol particles $(10-20 \mu \mathrm{m})$ were distinguished by the highest deposition efficiency $(0.85)$ in the human respiratory tract, and the finer particles $(0.3 \mu \mathrm{m})$ were distinguished by the lowest deposition efficiency (0.28). The heavy metal amount penetrating into the human respiratory tract with aerosol particles at different breathing rates has been evaluated. This shows that in Vilnius, taking into account average values, the pollution sources of these metals are not strong and there is no substantial threat to human health. It has been determined that the deposition efficiency of heavy met- als in the respiratory tract decreases slightly with the increase in the breathing rate, but with the threefold increase in the breathing rate (from 10 to $30 \mathrm{~L} \mathrm{~min}^{-1}$ ) the efficiency decreases only by about $10 \%$. On the average, about $60 \%$ ( $\sigma=6 \%$ ) of heavy metals present in the inhaled air penetrate into human airways. The comparison of the concentrations of $\mathrm{Pb}, \mathrm{V}$, and $\mathrm{Zn}$ in Vilnius city with those simultaneously measured at the Preila background station has shown that the concentrations differed up to two times.

\section{References}

[1] J.E. Fergusson, The Heavy Elements: Chemistry, Environmental Impact, and Health Effects (Pergamon Press, Oxford, England, 1990).

[2] J. Šakalys, K. Kvietkus, and D. Valiulis, Variation tendencies of heavy metal concentrations in the air and precipitation, Environ. Chem. Phys., 26(2), 61-67 (2004).

[3] C. Barbante, G. Cozzi, G. Capodaglio, K. van de Velde, C. Ferrari, A. Veysseyre, C.F. Boutron, G. Scarponi, and C. Paolo, Determination of Rh, Pd and Pt in polar and alpine snow and ice by double-focusing ICPMS with microconcentric nebulization, Anal. Chem. 71, 4125-4133 (1999).

[4] Aerosols: Research, Risk Assesment and Control Strategies, eds. S.D. Lee, T. Schneider, L.D. Grant, and P.J. Verkerk (Lewis Publishers, Chelsea, MI, USA, 1986) pp. 521-549.

[5] P. Žebrauskas and J. Valiūnienè, Human Anatomy and Physiology (Vilnius, 1987) [in Lithuanian].

[6] M. Berico, A. Luciani, and M. Formignani, Atmospheric aerosol in an urban area measurements of TSP and PM10 standards and pulmonary deposition assessments, Atmos. Environ. 31 (21), 3659-3665 (1997).

[7] L. Gradon and A. Podgorski, Kinetics of particle retention in the human respiratory tract, Ann. Occup. Hyg. 35(3), 249-259 (1991).

[8] O.G. Raabe, Comparision of the criteria for sampling inhalable and respirable aerosols, Ann. Occup. Hyg. 26(1), 33-44 (1982).

[9] E.J. Calabrese and E.M. Kenyon, Air Toxics and Risk Assessment (Lewis Publishers, 1991).

[10] D. Valiulis, D. Čeburnis, J. Šakalys, and K. Kvietkus, Estimation of atmospheric trace metal emissions in Vilnius city, Lithuania, using vertical concentration gradient and road tunnel measurement data, Atmos. Environ. 36(39-40), 6001-6014 (2002).

[11] V. Ulevičius, A. Juozaitis, and D. Šopauskienè, A high efficiency virtual impactor: Design and performance, Environ. Phys. 20(2), 20-26 (1998).

[12] D. Čeburnis and D. Valiulis, Fast, accurate and reliable analysis of trace metal air samples involving ultrasonic 
shaking and graphite furnace atomic absorption spectroscopy, in: Proceedings of the 4th European Furnace Symposium and XV Slovak Spectroscopic Conference, Podbanske, Slovakia, June 12-16, 2000, p. 125.

[13] L. Armbruster and H. Breuter, Investigations into defining inhalable dust, Ann. Occup. Hyg. 26(1), 2132 (1982).

[14] M.R. Bailey, F.A. Fry, and A.C. James, The long-term clearance kinetics of insoluble particles from the human lung, Ann. Occup. Hyg. 26(2), 273-290 (1982).

[15] A.R. Martin and W.H. Finlay, The effect of humidity on the size of particles delivered from metered-dose inhalers, Aerosol Sci. Technol. 39(4), 283-289 (2005).

[16] J.H. Seinfeld and S.N. Pandis, Atmospheric Chemistry and Physics: From Air Pollution to Climate Change (John Wiley \& Sons, 1998).
[17] K. Okada and J. Heintzenberg, Size distribution, state of mixture and morphology of Urbam aerosol, J. Aerosol Sci. 34(11), 1539-1553 (2003).

[18] Transboundary Particulate Matter in Europe, NILU: EMEP Report 4 / 2008.

[19] Controlling Fine Particulate Matter Under the Clean Air Act: A Menu of Options (STAPPA, ALAPCO, Washington, 2006).

[20] G. Mordas, The development of aerosol spectrometry and application in the investigation of aerosol dynamics, Ph.D. thesis (Institute of Physics, Vilnius, Lithuania, 2003).

[21] Optical Aerosol Spectrometer LAS 15M (Academy of Sciences of Lithuania, Institute of Physics, Vilnius, 1990) [in Russian].

\title{
SUNKIŲJŲ METALŲ PATEKIMAS İ ŽMOGAUS KVĖPAVIMO TAKUS VILNIUJE
}

\author{
D. Valiulis, J. Šakalys, K. Plauškaitė \\ Fizikos institutas, Vilnius, Lietuva
}

\begin{abstract}
Santrauka
Dèl intensyvios antropogeninès žmogaus veiklos ir miestų transporto gausos pasaulyje padidejo oro tarša aerozolio dalelèmis. Šių dalelių sudètyje yra įvairios kilmès toksinių medžiagų, alergenų ir sunkiųjų metalų, todèl ore esančios smulkios aerozolio dalelès yra žalingos žmogaus sveikatai. Patekusios i plaučius jos gali sukelti kvèpavimo takų ir kitas ligas. Priklausomai nuo gyvenimo būdo, suaugęs žmogus vidutiniškai įkvepia per dieną 15000 litrų oro. Darbo tikslas buvo ịvertinti sunkiųjų metalų kiekius, su aerozolio dalelèmis patenkančius į žmonių kvèpavimo takus Vilniuje. Aerozolio dalelių bandiniai sunkiųjų metalų analizei buvo imami prie Vilniaus televizijos bokšto 1999 m. spalio $28 \mathrm{~d}$. - gruodžio $20 \mathrm{~d}$. ir Vilniaus senamiesčio užterštumo tyrimo stoteleje $2001 \mathrm{~m}$. balandžio 28 d. - gegužès 17 d. Imant bandinius buvo registruojamas ir aerozolio dalelių dydžių spektras. Buvo nustatyta aerozolio dalelių sulaikymo žmogaus kvėpavimo takuose efektyvumo priklau-
\end{abstract}

somybė nuo dalelių dydžio ir kvėpavimo greičio. Atliekant eksperimentą buvo ištirti šeši 20-60 metu amžiaus atsitiktinai parinkti žmonès. Tyrimai buvo atliekami įkvepiant orą pro nosį ir iškvepiant pro burną skirtingais greičiais intervale nuo $10 \mathrm{iki} 321 \mathrm{~min}^{-1}$. Efektyvumas kito nuo 0,85 didžiosioms (10-20 $\mu \mathrm{m})$ iki 0,28 mažosioms $(0,3 \mu \mathrm{m})$ dalelèms. Iš šių duomenų nustatytas sunkiujų metalų kiekis, galintis patekti i žmogaus kvejpavimo takus Vilniuje. Lyginant $\mathrm{Pb}$, V ir Zn koncentracijas Vilniuje su šių metalų koncentracijomis Preilos foninèje stotyje matyti, kad jos skiriasi daugiausia iki dviejų kartų. Tai rodo, kad Vilniuje šių metalų šaltiniai nebuvo stiprūs ir žymesnio pavojaus žmonių sveikatai nekẻlè. Nustatyta, kad didèjant kvėpavimo greičiui, sunkiųjų metalų nusėdimas mažejja nedaug, o kvėpavimo greičiui išaugus trigubai, efektyvumas sumažeja tik apie 10\%. Vidutiniškai apie $60 \%(\sigma=6 \%)$ sunkiųju metalų, esančiu ịkvepiamame ore, patenka į kvejpavimo takus. 